\title{
PROFITABILITY ANALYSIS OF APPLE PRODUCTION IN THE REPUBLIC OF SERBIA
}

\author{
Miloš Pavlović ${ }^{1}$,Jovana Radoičić2 ${ }^{2}$, Miloš Milanović ${ }^{3}$ \\ *Corresponding author E-mail: jovanaradoicic91@gmail.com
}

\begin{abstract}
A R T I C LE IN F O
A B S T R A C T

Original Article

Received: 05 June 2020

Accepted: 02 July 2020

The subject of this paper is profitability analysis of apple production in the Republic of Serbia. The financial profitability analysis was performed in companies operating doi:10.5937/ekoPolj2003817P

UDC 338.432:634.11(497.11)

Keywords:

apple production, profitability analysis, Republic of Serbia in the territory of Vojvodina, Central and Eastern Serbia. This analysis was performed through the calculation of liquidity and profitability ratios. In the Republic of Serbia, 26658 hectares have apple orchards, which indicates that the cultivation of this fruit is highly represented. The aim of this paper is to determine whether apple production is a profitable activity in the Republic of Serbia, selecting three companies based on the analysis of profitability ratios.
\end{abstract}

JEL: Q12, Q14, R51

(C) 2020 EA. All rights reserved.

\section{Introduction}

Fruit growing as an area of plant production has a great potential for development in Serbia due to favorable climatic conditions for cultivation as well as growing demand for fruit in the domestic and world markets. However, fruit production in modern conditions is becoming increasingly complex, given the extremely high requirements in terms of fruit quality and the method of production (Milić, Lukač Bulatović, 2005).

Together with the food industry, the agricultural sector, in the strategy of economic development of the Republic of Serbia, represents the strategic potential of the Serbian economy (Stošić, Domazet, 2014). Fruit growing is a renewable resource, it contributes

1 Miloš Pavlović, Ph.D., Assistant Professor, Research Associate, Aplied studies Professor, Belgrade Business and Arts Academy of Applied Studies, Kraljice Marije street no. 73, 11000 Beograd; University of Priština, Faculty of Economics, Kolašinska street no.156, 38220 Kosovska Mitrovica Phone: +381 113042 300; +381 28497 934, E-mail: milospavlovic84@hotmail.com, ORCID ID (https://orcid.org/0000-0003-4112-6905)

2 Jovana Radoičić, Teaching associate, College of Economics Peć-Leposavić, Dositeja Obradovića street bb, 38218 Leposavić, Phone: +38128837 80, E-mail: jovanaradoicic91@, gmail.com, ORCID ID (https://orcid.org/0000-0002-3681-3877)

3 Miloš Milanović, Ph.D., Assistant Professor, University of Priština, Faculty of Economics, Kolašinska street no.156, 38220 Kosovska Mitrovica, Phone: +381 28497 934, E-mail: milos.milanovic@pr.ac.rs, ORCID ID (https://orcid.org/0000-0002-4684-6306)

http://ea.bg.ac.rs 
to sustainable development in the country, supports tourism and participates in preserving the environment (Sojkova, Adamičkova, 2011). No other branch of agriculture can bring as much profit as fruit growing, especially in hilly and mountainous areas (Keserović, 2004). However, fruit production can be considerably profitable only if the quality of products and fruit growing technologies are in line with market demands (Lukač Bulatović, Vukoje, Milić, 2017). The importance of fruit production also reflects in the fact that it employs a high percentage of labor per area unit. In addition to having a positive effect on the employment rate, fruit production is important due to thepositive nutritional value of apples.

Primary agricultural production and operations of agricultural enterprises in the Republic of Serbia are characterized by specific data that are reflected in seasonal activities, high production costs, slow working capital and long-term tying of funds (Vuković, Pijanić, Kalaš, 2018). In the past, the fruit production in Serbia was characterized by outdated assortments, semi-intensive and extensive plantations with inadequate planting material, low levels of cultural and pomological practice, poorer and uneven fruit quality and lack of adequate storage capacities (Lukač Bulatović, Nikolić Đorić, Đurić, 2019). In recent years, modern methods of cultivation and production with the application of technology have become more common in fruit growing. The key task of fruit production is to grow, store and satisfy the fruit market in sufficient quantity and quality to meet customer needs (Kudová, Chládková, 2008).

Our country has an excellent natural environment for growing almost all types of fruit trees (Šoškić, 2008). That is why the development of fruit tree production is backed by tradition. Serbia is located in a favorable area of northern latitude, with a climate which has four seasons and four climatic areas, very suitable for agriculture. The level of yield does not depend entirely on weather conditions, but implies a set of many factors that must ensure the traceability of certain activities and processes (Grujić, Roljević Nikolić, Subić, 2020). It include inadequate application of agrotechnical measures, unfavorable climatic conditions in certain stages of vegetation and so forth. Plantations should be grown with high quality and productive varieties of fruit species, which can achieve optimal production output and optimal economic results in the available agro-ecological conditions of the environment (Vukoje, Milić, 2009). Fruit growing is significant for the Republic of Serbia, as it makes up one tenth of the total agricultural production in the country. The most important fruit species in the fruit production of Serbia are apples, plums, raspberries and cherries. Fruit production of the Republic of Serbia has an advantageous development perspective due to favorable natural conditions for the growth of all continental fruit species and due to the growing demand for fruits and fruit products on the domestic and international market (Maksimović, 2018).

According to the data provided by the Republic Bureau of Statistics, the areas under orchards in Serbia amount to 183602 hectares. The largest areas under orchards are located in western Serbia, Šumadija, Podunavlje (Grocka and Smederevo) and in parts of southern Serbia. Relative to the total area under orchards, the largest part is under plum and apple orchards (Table 1). 
Table 1. Areas under stone fruit in the Republic of Serbia, 2018. (in hectares)

\begin{tabular}{|c|c|}
\hline Fruit species & Areas (ha) \\
\hline Apples & 26658 \\
\hline Pears & 4977 \\
\hline Quinces & 1947 \\
\hline Plums & 72923 \\
\hline Sour cherries & 19579 \\
\hline Peaches & 5176 \\
\hline Apricots & 6040 \\
\hline Cherries & 4335 \\
\hline
\end{tabular}

Source: Statistical Office of the Republic of Serbia, 2020

The research presented in this paper comes down to the profitability analysis of apple production in the Republic of Serbia. The analysis includes a presentation of liquidity and profitability ratios of apple production in three representative companies in the Republic of Serbia. Another aspect of this research is a comparative analysis of the profitability coefficients of apple production on their plantations. The companies were selected randomly, however, the criteria were that the companies are to operate in different regions of the Republic of Serbia (Vojvodina - Northern Serbia, Central Serbia and Eastern Serbia). Also, the authors defined a general hypothesis which reads: "Apple production in the Republic of Serbia is profitable."

\section{Materials and methodology}

Several research sources were used for this paper. The situation and trends in apple production in Serbia in the period from 2010 to 2018 will be reviewed based on statistical data taken from available statistical publications. The profitability analysis of apple production will be based on the analysis of liquidity and profitability ratios. Three agricultural companies from three different regions of Serbia (Vojvodina - Northern Serbia, Central Serbia and Eastern Serbia) will be used for the analysis. The coefficients analysis will be based upon their financial statements (balance sheet and income statement) for the 2017 and 2018 business years. Appropriate coefficients will be calculated for each company and their individual analysis will be presented. Finally, a comparative analysis of individual coefficients will be conducted and appropriate conclusions will be drawn. The authors selected the three companies by using the method of random selection, taking into account that the companies operating in the territory of different regions Vojvodina-Northern Serbia, Central Serbia and Eastern Serbia are represented.

On the territory of Vojvodina - Northern Serbia, this research analyzes the profitability of production of the medium-sized company "Ćirić Agro mđž doo". This company was founded in 2012 in the village of Titel near Novi Sad, with capacity to produce 15 types of top varieties of apples. The company has the most modern equipment for packaging and sorting fruit. In addition, the company owns the largest cold storage facility in Serbia, with a capacity of 22,000 tons. In addition to fruit growing, "Ćirić Agro mđž doo" is engaged in seed and intensive farming production on an area of over 2000 hectares. 
"Greeny doo" from Arandjelovac is the second company analyzed in this paper. It operates in the territory of Central Serbia. It currently grows a total of 85,000 apple trees of the following varieties: Golden Delicious, Red Chief, Jonagold, Granny Smith, Gala and Fuji. This company was founded in 2004, and its main activity is cultivating and storing apples. In 2012, the range of the company "Greeny" was expanded to the production of cherries and strawberries. The company has a fruit storage refrigerator with capacity of 2800 tons. In addition to fresh fruit, this agricultural company has supplemented its produces with the production of apple and beet juice. By size, it is classified as a small business.

When it comes to the region of Eastern Serbia, the randomly selected and analyzed agricultural company dealing with the production of apples is "Terra Optima". This company operates in the vicinity of Sokobanja. Founded in 2013, it organizes its production on a plantation area of 23 hectares. It focuses on the production of apples and different types of nuts. The apple varieties it produces are: Fuji KikuFubrax, Golden Delicious Reinders, Red Delicious Superchief and Granny Smith. This company is registered as a micro enterprise.

\section{Research Results and Discussion}

\section{Current state of apple production in the Republic of Serbia}

Apart from plums, apples are the most important fruit species grown on the territory of the Republic of Serbia. The development of fruit growing in general, as well as the production of apples, has a great impact on the input industry development. Good examples for it are plant protection products, mineral fertilizers, agricultural machinery, packaging, warehouse construction, etc. (Ivanović, Jeločnik, 2009). Favorable climate and soil conditions in Serbia are an excellent prerequisite for the development of this production. (Statistical Office of the Republic of Serbia, 2018).

Also, organic production represents the future and an opportunity to achieve aboveaverage earnings. This type of production is also interesting in the production of apples. In Serbia, they continue to experience organic production as a recreational business, although there is a clear direction, methods and legislation as well as extraordinary agro-ecological conditions. Willpower and coordination are needed activities, at all levels of agricultural policy, to the condition was improving. In the future, attention should be paid to the production of organic apples. (Pešić, 2020).

According to the results of the research conducted by the Statistical Office of Republic of Serbia, the most common apple types in the Republic of Serbia are varieties of the group "Ajdared", with 41\% in the total land area planted with apples, the second group consists of "other varieties" with $20 \%$, and the third most represented variety is "Zlatni delišes" (Golden Delight), which is represented by 14\% in the total land area planted with apples. In 2018, the average number of trees per hectare in the Republic of Serbia was 1688, and the total area under apples was 460404 hectares. Based on the data available on the website of the Food and Agriculture Organization of the 
United Nations (available at: http://www.fao.org/faostat), 239945 tons of apples were produced in the Republic of Serbia in 2010. The largest percentage increase in apple production in the Republic of Serbia compared to 2010 was recorded in 2013 (91\%) and 2018 (92\%), which also represents the largest amount of apples produced in tons in the observed period (Table 2).

Table 2. Apple production in the Republic of Serbia, 2011-2018. (t)

\begin{tabular}{|c|c|c|}
\hline Year & Production in tones & $\begin{array}{c}\text { Percentage of change compared to } \\
\mathbf{2 0 1 0}(\mathbf{\%})\end{array}$ \\
\hline 2011. & 265576 & $11 \%$ \\
\hline 2012. & 243987 & $2 \%$ \\
\hline 2013. & 458409 & $91 \%$ \\
\hline 2014. & 336313 & $40 \%$ \\
\hline 2015. & 431759 & $80 \%$ \\
\hline 2016. & 400473 & $67 \%$ \\
\hline 2017. & 378644 & $58 \%$ \\
\hline 2018. & 460404 & $92 \%$ \\
\hline
\end{tabular}

Source: FAO, 2020

In modern economies apples are usually marketed throughout the wholesale to a fruit packers or processors (Jeločnik, Subić, Kovačević, 2019). The production of apples, as well as other fruit species, does not only serve to meet the nutritive needs of the population. The produced fruit is also used as a raw material in the processing, pharmacyeutical and other industry branches. Meanwhile, processors use apples to produce apple sauce, or juice, spirits and cider, as well as to can, dry or freeze them, etc. (Crassweller, Kime, Harper, 2017). Aside from that, fruit as an export product is of great importance in increasing the country's foreign exchange incomes. As world top-ten apple producers could be listed: China, USA, Poland, Turkey, India, Iran, Italy, Russian Federation, France and Chile, among them, China is real super star, with total production (almost 44.5 million $\mathrm{t}$ ) higher than half of total world production (Khushboo, 2018). In 2018, 144,750 tons of apples were exported from Serbia, which was $26.7 \%$ less compared to the previous year (Table 3). According to the Ministry of Agriculture, Forestry and Water Management of the Republic of Serbia, of the total export of apples, most apples are traditionally exported to the Russian Federation, about $86 \%$, while other export countries are Italy, Bosnia and Herzegovina, Montenegro, Macedonia, Great Britain and others, and the yield of apples in the same year was 17.8 tons per hectare. (available at: http://www.minpolj.gov.rs/dokumenti/izvestaji-sa-trzista/). Based on the data from the Republic Bureau of Statistics, the purchase price in Serbia was 51.21 Serbian dinars per kilogram in 2018, which is a $40 \%$ increase compared to the purchase price of apples in 2013 (Table 4). 
Table 3. Export of apples from the Republic of Serbia, 2010-2017.

\begin{tabular}{|c|c|c|}
\hline Year & Export in tones & Export value (mil.dolars) \\
\hline 2010. & 107007 & 46,419 \\
\hline 2011. & 130182 & 65,799 \\
\hline 2012. & 61642 & 41,480 \\
\hline 2013. & 115938 & 53,025 \\
\hline 2014. & 135982 & 81,307 \\
\hline 2015. & 187366 & 104,097 \\
\hline 2016. & 232223 & 127,103 \\
\hline 2017. & 197601 & 124,678 \\
\hline 2018. & 144.750 & 101,004 \\
\hline
\end{tabular}

Source: FAO, 2020

Table 4. Purchase prices of apples, 2013-2018.

\begin{tabular}{|l|l|l|l|l|l|l|}
\hline Year & 2013. & 2014. & 2015. & 2016. & 2017. & 2018. \\
\hline $\begin{array}{l}\text { Purchase price } \\
\text { din/kg }\end{array}$ & 37,28 & 40,76 & 42,93 & 46,09 & 54,96 & 52,21 \\
\hline
\end{tabular}

Source: The Statistical Office of the Republic of Serbia, 2020

Based on data of credit approval in agriculture, presented on Agropresswebsite - The Association of Agricultural Journalists initial investment per hectare of sour cherries range from 10-15,000 euros, including modern cultivation technology. On the other hand, cultivation of cherries requires greater investments, 60,000 euros per hectare, while the initial investment for growing blueberries is 30-50,000 euros per hectare. Contrastingly, growing apples appears to be one of the most common fruit species for cultivation in Serbia as it requires an initial investment of 50-60,000 euros per hectare, which includes an irrigation system, hailstorm protection system as well as frost protection system. However, based on the same research there were additional results which indicate that there are other, more affordable planting systems. For example: 5,000 euros / hectare for extensive plantations, semi-intensive plantations for 10,000 euros / hectare, modern dense plantations without an irrigation and drainage system for 20,000 euros/ hectare. This research indicates that the payback period for investments in apple orchards is 4.4 years (available at: https://www.agroklub.rs/vocarstvo/jabukazahteva-ulaganja-ali-ima-dobre-prinose-i-kvalitet-ploda/43786/).

\section{Liquidity Indicators}

The financial analysis serves as a compass as well as a reliable guideline for the choice of the appropriate developmental course which is intended to enhance the progress of a company (Draganac, 2016). Financial information is used to meet the following needs of agricultural enterprises for decision-making, as well as for financial reporting purposes (Mitrović, Knežević, Veličković, 2015). 
Liquidity is defined as the ability of an enterprise to cover its immediate debts and obligations. It is the ability of a company to respond to its financial obligations on time and in full. Liquidity is associated with the ability of a company to transform its assets into cash, because cash is absolutely liquid and is used as a measure of liquidity of other assets of the company. The presented indicators that indicate the liquidity situation of the three companies are the current liquidity ratio, the accelerated liquidity ratio, the current liquidity ratio and the financial stability ratio.

The current liquidity ratio of the "Ćirić Agro mđž doo" company indicates that every Serbian dinar of short-term liabilities in 2017 was covered with 0.94 Serbian dinars of current assets of the company. Current liquidity is some kind of precondition for ensuring that company is able to meet their short-term obligations (Vuković, Jakšić, 2019). Current liquidity has increased to 1.80 the following year. The accelerated liquidity ratio in this company also increased in 2018. Namely, in 2017, this coefficient was 0.29 and he said that every dinar of short-term liabilities was covered with 0.29 dinars of liquid assets that the company owns. In 2018, that coefficient was increased to 1.80 . The accelerated liquidity ratio of this company also increased in 2018. Namely, in 2017, this coefficient was 0.29 and it indicated that every Serbian dinar of short-term liabilities was covered with 0.29 Serbian dinars of liquid assets that the company owns. In 2018, that coefficient was increased to 1.80 . The current liquidity ratio indicates the ability of a company to immediately settle its financial obligations. For this company, this ration was 0.03 in 2018, while in 2018 it increased to 0.09 . The financial stability ratio indicates the ratio between long-term assets and capital with addition of longterm liabilities. The lower the value ratio, the more liquid company is. In the case of company "Ćirić Agro mđž doo", in 2017 this ratio was 1.00, therefore in 2018 there was a positive change in the coefficient of financial stability and it was 0.90 (Table 5).

The current liquidity ratio in the company "Greeny Arandjelovac" in 2017 was 3.25, which means that each Serbian dinar of short-term liabilities was covered with 3.25 dinars of current assets of the company. This coefficient increased slightly in the following year, amounting to 3.51. The accelerated liquidity ratio in 2017 indicates that every Serbian dinar of short-term liabilities is covered by 1.03 Serbian dinars of the company's liquid assets. This coefficient has slightly decreased in 2018 and amounted to 1.02 . The current liquidity ratio indicates that the company "Greeny Arandjelovac" in 2017 had more cash and cash equivalents and was more willing to meet its current financial obligations compared to 2018. Namely, this ratio was 0.21 in 2017 and 0.08 in 2018. The coefficient of financial stability in 2017 was 0.75 . It did not change much in 2018 and amounted to 0.76 (Table 6).

When it comes to "Terra Optima" company, the current liquidity ratio increased in 2018 and amounted to 0.39 . A decrease in short-term assets was recorded in this company in 2017 , bringing it down to 0.11 . The accelerated liquidity ratio indicates that this company had a reduced amount of liquid assets in 2017 compared to 2018. This is the reason for this ratio to increase from 0.12 to 0.18 . The current liquidity ratio is at a very low level in both observed years. In 2017 it was 0.002 , and in 2018 it was 0.003 . 
The reason for this is the low level of cash and cash equivalents in the company. The coefficient of financial stability was lower and amounted to 1.39 in 2017, while it was 1.42 in 2018. This indicates that "Terra Optima" was more liquid in 2017 (Table 7).

Table 5. Liquidity indicators of apple production of producer "Ćirić Agro mđž doo", (2017-2018)

\begin{tabular}{|c|c|c|}
\hline Coefficient / year & $\mathbf{2 0 1 7}$ & $\mathbf{2 0 1 8 .}$ \\
\hline Current liquidity ratio & 0,94 & 1,80 \\
\hline Accelerated liquidity ratio & 0,29 & 0,39 \\
\hline Current liquidity ratio & 0,03 & 0,09 \\
\hline Coefficient of financial stability & 1,00 & 0.90 \\
\hline
\end{tabular}

Source: Author's calculation based on the financial statements data of apple production in "Ćirić Agro mđž doo"

Table 6. Liquidity indicators of apple production of producer "Greeny Aranđelovac" (2017-2018)

\begin{tabular}{|c|c|c|}
\hline Coefficient / year & $\mathbf{2 0 1 7}$ & $\mathbf{2 0 1 8 .}$ \\
\hline Current liquidity ratio & 3,25 & 3,51 \\
\hline Accelerated liquidity ratio & 1,03 & 1,02 \\
\hline Current liquidity ratio & 0,21 & 0,08 \\
\hline Coefficient of financial stability & 0,75 & 0,76 \\
\hline
\end{tabular}

Source: Author's calculation based on the financial statements data of apple production in "Greeny Aranđelovac"

Table 7. Liquidity indicators of apple production of producer „Terra Optima“ (2017-2018)

\begin{tabular}{|c|c|c|}
\hline Coefficient / year & 2017. & $\mathbf{2 0 1 8 .}$ \\
\hline Current liquidity ratio & 0,11 & 0,39 \\
\hline Accelerated liquidity ratio & 0,12 & 0,18 \\
\hline Current liquidity ratio & 0,002 & 0,003 \\
\hline Coefficient of financial stability & 1,39 & 1,42 \\
\hline
\end{tabular}

Source: Author's calculation based on the financial statements data of apple production in ,Terra Optima“"

Based on the liquidity ratio analysis, it turned out that the company "Greeny Arandjelovac" has the most liquidity, the coefficient of accelerated liquidity is more than 1 only in this company (1.03 and 1.02), which is not the case with the other two companies. The current liquidity ratio should be at least 1 , however, this is not the case with any of the three analyzed companies. Based on the current liquidity ratio, which should be 2, the company "Greeny Arandjelovac" operates with most liquidity (3.25 and 3.51). The coefficient of financial stability in both observed years is the lowest in the same company, which indicates this is the business with superior liquidity $(0.75$ and 0.76$)$. 


\section{Profitability Indicators}

Profitability is a basic performance indicator that measures the success of a company's business and contributes to its better reputation (Tomašević, Jović, Vlaović-Begović, 2019). It is defined as the ability of a company to make profit from all business activities. Profitability is also the ability to earn on the basis of investment (Adjirackor, et all). Profit is the main motive of any organization and profitability ratios help evaluate the success of an enterprise.

Profitability ratios measure the ability of a company to create profit in relation to their expenses. Recording a higher profitability ratio compared to the previous period of financial reporting is an indicator of improved financial situation. Profitability ratios can also be compared to the same ratio of a similar company to determine how profitable the business is relative to competitors. The coefficients used in the profitability analysis of the three firms are the net profit margin, the rate of return on assets (ROA) and the rate of return on equity (ROE).

The net profit margin represents the percentage of income that remains as freely available profit. It gives a final picture of how profitable the company is after taking into account all expenses, including interest and taxes. The reason that the net profit margin is used as a measure of profitability is that it includes everything in the analysis. It is a coefficient used to calculate the percentage of profit that a company produces from its total revenue. It compares net profit to the total income of the company.

Another coefficient for measuring profitability is the rate of return on assets (ROA). Return on Assets (ROA) is an indicator that showed the efficiency of the company at generating profits from each unit of shareholders equity, in order to explain to what extent does the company use investments in order to earn a profit (Alshatti, 2015). The higher the ratio, the better the company uses its assets and has a higher return on assets. It represents the ratio between net profit and total assets. Companies that operate in capital-intensive industries, and have a high volume of fixed assets, will generally have a lower ROA because the amount of the denominator in the calculation formula is immediately increased. Therefore, this ratio is mainly used to measure the profitability of companies operating in the same industry.

The third analyzed profitability ratio is the rate of return on equity. Return on equity is an important measure of a company's profitability. Higher values of this ratio are favorable, meaning that the company generates income on invested equity. However, the analysis of this coefficient must be approached seriously. If the ROE increase happens while the shareholder equity decreases, it results with the use of borrowed funds (debt), which means that the company operates with higher risk.

Indicators of profitability of apple production of the producer "Ćirić Agro mđž doo" are shown in Table 8. The net profit margin in 2017 was 0.15 , and in 2018 this coefficient increased to 0.30 . This means that in 2017 , this company produced $15 \%$ of the profit from its total income - it earned $15 \%$ of the total income that remained as a profit after 
deducting all costs, interest and taxes. The following year, this percentage increased to $30 \%$, because the amount of total revenues increased in the same year. The rate of return on assets (ROA) at the company "Ćirić Agro mđž doo" was 0.04 in 2017, and 0.09 in 2018. The ratio is higher in 2018, which is a good indicator of profitability. This is the result of a decrease in the amount of total assets and an increase in net profit. The ROE coefficient was 0.06 in 2017 and 0.12 in 2018. This means that this company returned $6 \%$ of the invested capital in 2017 , while in the following year it returned $12 \%$ of the invested capital.

Profitability coefficients of apple production for the producer "Greeny Arandjelovac" are presented in Table 9. The net profit margin in 2017 was 0.03 and in 2018 it was 0.02 . Therefore, in 2017 , this company produced $3 \%$ of the profit from its total income, and in 2018, that coefficient was reduced to $2 \%$. The rate of return on assets (ROA) at this company was 0.08 in 2017 and 0.06 in 2018. The coefficient decreased, due to the fact that the total assets increased in 2018 compared to 2017. The ROE of the company "Greeny Arandjelovac" in 2017 was 0.09, meaning that this company returned 9\% of the invested capital. The following year, this ratio was 0.07 (2018), which means that this company returned $7 \%$ of the invested capital.

Indicators of profitability of apple production produced by "Terra Optima" are shown in Table 10. Namely, the net profit margin of this company in 2017 was 0.01 and 0.02 in 2018, which means that the company earned $1 \%$ of the total revenue in 2017 , and the following year $2 \%$. The second analyzed coefficient of profitability of this company is the rate of return on assets (ROA). It was 0.08 in 2017, and the following year it was 0.06 due to the increase in total assets. The company's ROE dropped slightly in 2018. Namely, in 2017, this company returned 4\% of the invested capital, and the following year, the rate of return on capital was $3 \%$.

Table 8. Profitability indicators of apple production of producer "Ćirić Agro mđž doo" (20172018)

\begin{tabular}{|c|c|c|}
\hline Coefficient / year & $\mathbf{2 0 1 7}$ & $\mathbf{2 0 1 8 .}$ \\
\hline Net profit margin & 0,15 & 0,30 \\
\hline Return on Assets (ROA) & 0,04 & 0,09 \\
\hline Return on Equity (ROE) & 0,06 & 0,12 \\
\hline
\end{tabular}

Source: Author's calculation based on the financial statements data of apple production in "Ćirić Agro mđž doo"

Table 9. Profitability indicators of apple production of producer "Greeny Aranđelovac" (20172018)

\begin{tabular}{|c|c|c|}
\hline Coefficient / year & $\mathbf{2 0 1 7 .}$ & $\mathbf{2 0 1 8 .}$ \\
\hline Net profit margin & 0,03 & 0,02 \\
\hline Return on Assets ROA) & 0,08 & 0,06 \\
\hline Return on Equity (ROE) & 0,09 & 0,07 \\
\hline
\end{tabular}

Source: Author's calculation based on the financial statements data of apple production in "Greeny Aranđelovac" 
Table 10. Profitability indicators of apple production of producer , Terra Optima“

(2017-2018)

\begin{tabular}{|c|c|c|}
\hline Coefficient / year & $\mathbf{2 0 1 7}$ & $\mathbf{2 0 1 8 .}$ \\
\hline Net profit margin & 0,01 & 0,02 \\
\hline Return on Assets (ROA) & 0,003 & 0,002 \\
\hline Return on Equity (ROE) & 0,04 & 0,03 \\
\hline
\end{tabular}

Source: Author's calculation based on the financial statements data of apple production in „Terra Optima““

\section{Comparative profitability analysis}

Table 11 provides a comparative analysis of the profitability indicators of the three analyzed companies for 2017. Based on the data from Table 14, it can be stated that the company "Ćirić Agro mđž doo" achieved a net profit margin of 0.15, which is higher compared to the other two companies. The company "Greeny Arandjelovac" achieved a net profit margin of 0.03. The company "Terra Optima" had the best results in 2017, with a profit margin of 0.01 . In addition, the analysis of this company indicates the lowest values for the remaining two profitability ratios. Namely, in 2017, the rate of return on assets was 0.003 , and the rate of return on equity was 0.04 . In 2017, the rates of return on assets (ROA) and equity (ROE) were the highest in the company "Greeny Arandjelovac", the first was 0.08 and the second 0.09. In 2017, "Ćirić Agro mđž doo" company had a0.04rate of return on property, while the rate of return on capital was 0.06 .

Table 11. Profitability indicators, 2017.

\begin{tabular}{|c|c|c|c|}
\hline $\begin{array}{c}\text { Company / } \\
\text { coefficient }\end{array}$ & Net profit margin & $\begin{array}{c}\text { Return on Assets } \\
\text { (ROA) }\end{array}$ & Return on Equity (ROE) \\
\hline Ćirić Agro mđž doo & 0,15 & 0,04 & 0,06 \\
\hline Greeny Aranđelovac & 0,03 & 0,08 & 0,09 \\
\hline Terra Optima & 0,01 & 0,003 & 0,04 \\
\hline
\end{tabular}

Source: Author's calculation

Table 12 presents a comparative analysis of profitability indicators for the analyzed companies for 2018. Namely, "Ćirić Agro mđž doo" recorded the highest net profit margin in 2018 - it amounted to 0.30 or $30 \%$, while in the companies "Greeny Aranđelovac" and "Terra Optima" recorded the same margins which amounted to $2 \%$. In 2018, the company "Ćirić Agro mđž doo" had the highest rate of return on assets (ROA) compared to the other two companies (0.09). In the case of "Greeny Arandjelovac", the ROA coefficient was 0.06, while the lowest value for the asset return rate in 2018 was recorded in the company "Terra Optima" (0.002). The rate of return on equity in 2018 was also the highest in the company "Ćirić Agro mđž doo" (0.12), while "Greeny Arandjelovac" had 0.07, and "Terra Optima" had 0.03. 
Table 12. Profitability indicators, 2018.

\begin{tabular}{|c|c|c|c|}
\hline Company / coefficient & Net profit margin & Return on Assets (ROA) & $\begin{array}{c}\text { Return on Equity } \\
\text { (ROE) }\end{array}$ \\
\hline Ćirić Agro mđž doo & 0,30 & 0,09 & 0,12 \\
\hline Greeny Aranđelovac & 0,02 & 0,06 & 0,07 \\
\hline Terra Optima & 0,02 & 0,002 & 0,03 \\
\hline
\end{tabular}

Source: Author's calculation

\section{Conclusion}

Based on the conducted analysis, the net profit margin for 2017 and 2018 in two out of the three analyzed companies was lower than $10 \%$. Only one of the three analyzed companies recorded a net profit margin of more than $10 \%$ (15\% in 2017 and $30 \%$ in 2018), which means that only one out of three companies was profitable and that only one company produced apples in 2017 and 2018 with profit. This indicates that apple production is not a profitable activity in the Republic of Serbia and that the hypothesis "Apple production in the Republic of Serbia is profitable" has been refuted. However, it must be noted that the hypothesis cannot be fully refuted, due to the fact the conclusion was made only on the basis of analyzing three randomly selected companies operating in different regions of the Republic of Serbia. The criteria for selecting the companies was the coverage of the entire country.

\section{Conflict of interests}

The authors declare no conflict of interest.

\section{References}

1. Abbas, D. (2019). Activity Ratio influence on Profitability (At the Mining Company Listed in Indonesia Stock Exchange Period 2010-2013), 48-69. doi: https://doi. org/10.17605/OSF.IO/7G2VP

2. Serbia Business Register Agency, financial statements of companies "Ćirić Agro mđž doo" „Greeny Aranđelovac“, „Terra Optima“, Retrieved from https://www. apr.gov.rs/\%D0\%BF\%D0\%BE\%D1\%87\%D0\%B5\%D1\%82\%D0\%BD\%D0\%B0. 3.html (April 01, 2020).

3. Agroclub of the Republic of Serbia, Retrieved from https://www.agroklub.rs/ vocarstvo/jabuka-zahteva-ulaganja-ali-ima-dobre-prinose-i-kvalitet-ploda/43786/ (May 25, 2020).

4. Adjirackor, T., Asare, D., Asare, F., Gagakuma, W., \& Okogun Odompley, J. (2017). Financial Ratios as a Tool for Profitability in Aryton Drugs. Research Journal of Finance and Accounting, 8(1), 1-10. 
5. Alshatti, S. (2015). The Effect of the Liquidity Management on Profitability in the Jordanian Commercial Banks. International Journal of Business and Management, 10(1), 62-71. doi: https://doi.org/10.5539/ijbm.v10n1p62

6. Crassweller, R.M., Kime, L.F., \& Harper, J.K. (2017). Apple production, Agricultural Alternatives Series, Penn-State Extension, Pennsylvania State University, University Park, USA, 1-12, Retrieved from https://extension.psu.edu/ appleproduction (August 24, 2020).

7. Draganac, D. (2016). Comparative analysis of functional producers' Profitability in Serbia- a leader- follower relation. Economics of Agriculture, 63(2), 547-566. doi: https://doi.org/10.5937/ekoPolj1602547D

8. Grujić, B., Roljević Nikolić, S., \& Subić, J. (2020). Tendencies of plant production in the Republic of Serbia and at the level NUTS 1. Journal of Agricultural Sciences, 65(1), 69-84. doi: https://doi.org/10.2298/JAS2001069G

9. Ivanović, L., \& Jeločnik, M. (2009). Analysis and Planning of Apple Production As Factor of Rural Development Support. Economic Analysis, 42(3-4), 78-85.

10. Jeločnik, M., Subić, J., \& Kovačević, V. (2019). Konkurentnost prerade jabuke. Ekonomika, 65(4), 41-51. doi: https://doi.org/10.5937/ekonomika1904041J

11. Keserović, Z. (2004). Savremene tendencije u proizvodnji jabuke i kruške, Zadružni savez Vojvodine, Novi Sad. (Contemporary tendencies in apple and pear production, Cooperative Association of Vojvodina, Novi Sad).

12. Kudová D., \& Chládková, H. (2008). Barriers to the entry into the fruit producing industry in the Czech Republic. Agricultural Economics - Czech, 54, 413-418. doi: https://doi.org/10.17221/2700-AGRICECON

13. Khushboo, S. (2018). Top Apple Producing Countries in the World, Portal of Worldatlas, St. Laurent, Canada, Retrieved from https:/www.worldatlas.com/ articles/topapple-producing-countries-in-the-world.html (August 24, 2020).

14. Lukač Bulatović, M., Vukoje, V., \& Milić, D. (2017). Economic indicators of the production of important fruit-specific species in Vojvodina. Economics of Agriculture, 64(3), 973-985. doi: https://doi.org/10.5937/ekoPolj1703973L

15. Lukač Bulatović, M., Nikolić Đorić, E., \& Đurić, K. (2019). Analysing and forecasting trends in the apple production in Serbia. Journal on Processing and Energy in Agriculture, 23(1), 27-31. doi: https://doi.org/10.5937/jpea1901027L

16. Maksimović, B. (2018). Proizvodnja i izvoz voća i prerađevina iz Srbije: stanje međunarodni faktori uspeha, Institut za ekonomiku poljoprivrede, Beograd.

17. Milić, D., \& Lukač Bulatović, M. (2005). Stanje i tendencije proizvodnje voća u Srbiji, Poljoprivredni fakultet, Departman za ekonomiku poljoprivrede i sociologiju sela, Novi Sad.

18. Ministry of Agriculture, Forestry and Water Economy of the Republic of Serbia, Retrieved from http://www.minpolj.gov.rs/dokumenti/izvestaji-sa-trzista/ (April 11, 2020). 
19. Mitrović, A., Knežević, S., \& Veličković, M. (2015). Ratio analysis specifics of the family dairies' financial statements. Economics of Agriculture, 62(4), 1061-1078. doi: https://doi.org/10.5937/ekoPolj1504061M

20. Statistical Office of the Republic of Serbia, Retrieved from https://www.stat.gov. rs/ (April 04, 2020).

21. Pešić, B. (2020). Analysis of organic livestock and crop production in Serbia. Ecologica, 27(98). 195-202.

22. Sojkova, Z., \& Adamičkova, I. (2011). Evaluation of economic efficiency of the orchard's investment project with respect to the risk. Agricultural Economics Czech, 57(12), 600-608. doi: https://doi.org/10.17221/104/2011-AGRICECON

23. Stošić, I., \& Domazet, I. (2014). Analiza konkurentnosti poslovanja i potencijali rasta privrede Srbije u periodu svetske krize. Teme: časopis za društvenu teoriju $i$ praksu, 38(2), 491-506.

24. The Food and Agriculture Organization of the United Nations (FAO), Retrieved from http://www.fao.org/faostat/en/\#data/QC (April 05, 2020).

25. The Association of Agricultural Journalists, Retrieved from http:/www.agropress.org.rs/cir/ rubri/biljn-pr-izv-dnj/v-c-rs-v-i-vin-gr-d-rs-v/item/5057-krediti-za-mlade-poljoprivrednikeevo-koja-proizvodnja-je-najisplativija?fbclid=IwAR1y4Egl-3bJk2bXnZHz6BZ_GE3GQgyaByaTmFB5mX4_GrQyemPpWTTJPk (May 25, 2020).

26. Tomašević, S., Jović, Z., \& Vlaović-Begović, S. (2019). Uticaj veličine preduzeća na profitabilnost poljoprivrednih preduzeća u Republici Srbiji. Journal of Agricultural Sciences Belgrade, 64(3), 293-302. doi: https://doi.org/10.2298/JAS1903293T

27. Vuković, B., \& Jakšić, D. (2019). The effect of Working Capital Management on Profitability: Evidence from Southeast Europe. Economics of Agriculture, 66(1), 159-172. doi: https://doi.org/10.5937/ekoPolj1901159V

28. Vuković, B., Pjanić, M., \& Kalaš, B. (2018). Analiza likvidnosti poljoprivrednih preduzeća AP Vojvodine. Anali Ekonomskog fakulteta u Subotici, 54(39), 205-217.

29. Šoškić, M. (2008). Savremeno voćarstvo, Beograd. (Contemporary fruit growing, Belgrade). 